
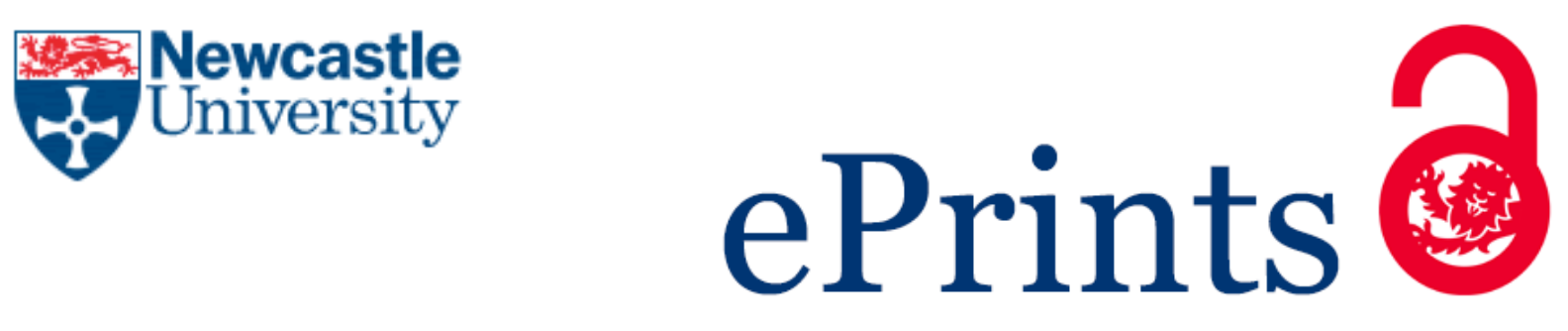

Smith Finley J. Whose Xinjiang? Space, Place and Power in the Rock Fusion of Xin Xinjiangren, Dao Lang. In: Hayes, A.; Clarke, M, ed. Inside Xinjiang : Space, Place and Power in China's Muslim Far Northwest. London: Routledge, 2015, pp.75-99.

\title{
Copyright:
}

This is an Accepted Manuscript of a book chapter published by Routledge in Inside Xinjiang : Space, Place and Power in China's Muslim Far Northwest on 18/12/2015, available online:

http://www.routledge.com/9781138780798

Date deposited:

$21 / 12 / 2015$

Embargo release date:

18 June 2017

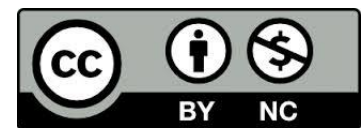

This work is licensed under a Creative Commons Attribution-NonCommercial 3.0 Unported License 


\section{Whose Xinjiang? Space, Place and Power in the Rock Fusion of Xin Xinjiangren, Dao Lang}

Joanne Smith Finley, Newcastle University, UK

(Word Count: Total-11938 words; Text-only-10509 words)

\section{Introduction}

In this chapter, I explore how geo-political space (Xinjiang, or the 'New Frontier'), cultural identity and belonging to place are represented and contested through the audio texts (lyrics, vocal styles and instrumentation) and visual texts (music packaging, music videos) of Chinese Mando-pop artist, Dao Lang. A Sichuanese (Han) migrant to regional capital, Ürümchi, Dao Lang paints himself as a Xin Xinjiangren or 'new Xinjiangese'. Drawing on traditional Uyghur musical instrumentation to infuse his soft rock ballads, he lives out the romantic vision of a solitary soul suspended in a silent and empty desert landscape (terra nullius). At the same time, the Dao Lang project seeks to bridge the cultural chasm between the inhabitants of Xinjiang (including indigenous groups such as the Uyghurs and Kazakhs, and newcomers such as Han and Hui in-migrants) and Han Chinese living in China proper. What emerges is an ideal vision of a new, all-inclusive regional identity: within Dao Lang's art, Xinjiang the territory is a distinct and unique part of China, populated by women Xinjiangren (We Xinjiangese), conceived as a united body of subscribers to an ancient Central Asian culture fused with Chinese characteristics. The various peoples of Xinjiang, who share the most beautiful melodies emanating from Central Asia, as well as the fruits (natural resources) of the region, should have no reason, the singer argues, to come into conflict. Yet a close analysis of the song Wolf in Sheepskin (2006) seems to tell a different metaphorical tale: one of local aversion to cultural fusion symbolised by the impossibility of inter-ethnic courtship. In revealing the fragility of Dao Lang's inclusive conceptualisation of space and place, the song illustrates the two-way power dynamics and tensions that characterise contemporary Uyghur-Han relations, and foreshadows the singer's flight from Xinjiang following the 2009 Ürümchi riots.

\section{Xinjiang the geo-political space}

It is necessary first to situate the Uyghurs (and indeed the Han Chinese) within the context of politically contested territory. The Uyghurs originated on the steppes of what is today's Mongolian Republic. Defeated in battle by Kyrgyz nomads in $840 \mathrm{CE}$, they abandoned their Orkhon kingdom and migrated westward in three groups. One of those groups settled in the region now called Xinjiang in $845 \mathrm{CE}$, where they fused with indigenous Indo-European farmers and turned to a sedentary lifestyle (Geng 1984, p. 6). The Uyghurs speak a TurkicAltaic language and, though they have subscribed to a diversity of religious beliefs over the course of their group history, the contemporary Uyghurs have been adherents of Islam - to varying degrees - for at least 500 years (Bellér-Hann 2008, pp. 303-6). Meanwhile, the territory they have inhabited for well over a millennium was not fully or meaningfully 
incorporated into the Chinese empire until the Qing reconquest in 1878, a fact reflected in the name given to the newly created province, Xinjiang (or 'New Frontier') (Millward 2007, pp. 124-46).

The Han are the majority ethnic group in the People's Republic of China, accounting for 91.51 per cent of the total population according to the 2010 census (National Bureau of Statistics of China 2011). Yet, reflecting China's short history of direct political control over Xinjiang, the proportion of Han within the regional population amounted to just 5 per cent prior to CCP accession in 1949 (Toops 2004, p. 245). In order to bring political stability to the Western peripheries and further China's 'civilizing mission' (Harrell 1994), the CCP embarked in the early 1950s upon a programme of Han population transfer. According to the most recent PRC national census conducted in 2010, Han Chinese now account for some 39 percent or 8,416,867 persons, compared to the Uyghurs, who account for 46.4 percent or $10,019,758$ persons. ${ }^{1}$

However, the conceptual frame does not stop at contested territory; it involves also the contestation of cultural identity and place: 'Both as a creative practice and as a form of consumption, music plays an important role in the narrativization of place, that is, in the way in which people define their relationship to local, everyday surroundings' (Bennett 2004, p. 2). In this sense, specific musics become 'symbolic anchors' in a region and signs of belonging (Lewis, cited in Bennett 2004, p. 3). Not only this, but everyday objects and commodities (such as music CDs and music reviews) may possess an emotive force in the ways in which they are used to delineate, reinforce or transform identities and positions, as well as notions of tradition and authenticity (Milgram 2005, p. 231).

\section{Parallel yet separate soundscapes}

The ethnomusicologist Rachel Harris, writing on the Xinjiang soundscapes of the 1990s, spoke of 'parallel musical worlds': one dominated by covers of Uyghur traditional folk songs, translated into Chinese and sung by Han composer, Wang Luobin (王洛賓); the other by original songs produced and recorded by Uyghur performers and sung in the long-time regional lingua franca of Uyghur. The two worlds were entirely separate (Harris 2005a, p. 387). Within the latter world, two 'Voices of the Uyghurs', each a singer-dutarist, competed in the articulation of alternative representations through the medium of 'new folk'. ${ }^{2}$ In this new vision of the Han-Uyghur relationship, the Han no longer appeared as the benevolent 'older brother' in the 'great family of nationalities'; instead he was cast as 'coloniser' to the Uyghur 'colonised'. In this way, each artist firmly rejected ideal state discourses of 'nationality equality' (minzu pingdeng) and 'nationality unity' (minzu tuanjie) and promoted an alternative truth (Smith 2007; Smith Finley 2013a). Following disturbances in Ghulja (Yining) in 1997, heavy restrictions were placed on freedom of speech in order to suppress the oral expression of negative ethnic stereotypes, considered to have exacerbated inter-ethnic tensions. Intensified censorship within the cultural sector followed (Bequelin 2004), so that it now became impossible to express political ideas in lyrical metaphor. Into this vacuum came Han migrant Dao Lang, the model 'Xin Xinjiangren' (New Xinjiangese), who produced songs 
and cultural products embodying fusion and unity on musical, cultural, social and political levels.

\section{Dao Lang the man}

Dao Lang (original name, Luo Lin) was born in Sichuan province in 1971. As a child, he was exposed to minority musics from an early age, and would listen to Xinjiang folksongs played to him by his father on an old record player. Something of a hermit - 'Actually, I am an ascetic in the world of music' (China Internet Information Centre 2004) - Dao Lang quit secondary school at the age of seventeen, and left home for Neijiang city, where he learned to play keyboards. Two years later, he was bar-hopping in Chengdu, Chongqing, Xi' an, and in Tibet. Asked in interview about his 'wandering years', Dao Lang stated that he had wished to 'venture out into the world' (chu qu chuang), and quoted a Jin dynasty proverb to paint himself as a pioneer: a man of broad ambition, willing to travel to distant places to further a great cause (hao nan'er zhi zai sifang) (Xiao, Shi and Chen 2011). He toured for more than four years until he eventually met his second wife, Zhu Mei, in Hainan in 1995 (China Internet Information Centre 2004). She, a Han Chinese born and raised in Xinjiang, subsequently 'took him home' to the region, where they settled in Ürümchi. Failing in his original musical enterprises (which included writing advertising jingles for local radio and releasing a CD of sundry pop music), in 2001 Dao Lang buried himself in a library to reflect on his situation. When he had first arrived in Xinjiang, he knew nobody, and, to divert him, his wife would play him local Xinjiang music. This finally inspired Dao Lang to set out to meet the local Uyghur people. Travelling to the Tarim basin, he discovered the beautiful music and dance culture of the Dolan Uyghurs (he would later adopt this ethnonym as his artistic name). ${ }^{3}$ Feeling 'recharged', he produced an album with the stated aim of 'promoting the Xinjiang region' to Han in China proper.

His first successful release, Love Songs from the Great Desert (大漠情歌 Damo qingge) (2002) was a collection of minority folksongs, re-arranged and sung by Dao Lang. In his own words, all but four songs were 'oldies written by others' (China Internet Information Centre 2004). I shall return to this point later. The album nudged open the door of his success: 'It was like a fire spreading quickly from Xinjiang to the northeast, Shanghai, Guangzhou, Xi'an, Chengdu and other areas of the country. The only city that remained unmoved was Beijing' (China Internet Information Centre 2004). However, it was his next release, Turkestan Love Songs (西域情歌 Xiyu qingge) (2003), ${ }^{4}$ which became Dao Lang's first big hit in Xinjiang. Like the previous album, this was a compilation of covers of twelve traditional songs from the region. In the wake of its success, the artist ceased to perform under his personal name of Luo Lin, and fully adopted his chosen stage name: 'Using the name Dao Lang is also to promote this remote city [sic] to my countrymen, the beauty of this region, a place that has nurtured me and given me tremendous opportunities' (China Internet Information Centre 2004). His third album The First Snows of 2002 (2002 年第一场雪 2002 nian diyi chang хие) (2004) finally secured his fame at a national level, selling a total of 2.7 million copies. In particular, the title track, released in January 2004, resonated throughout China and beyond to the outside world (Xin 2012). 
From the beginning, Dao Lang has presented himself, and been characterised in the media, as the reluctant superstar: he is a loner, a hermit, a family man. In keeping with this image and his personality, the artist only rarely gives interviews, to the frustration of his adoring fans. Following his rise to fame in 2004, the singer explained: 'I don't want to show off; [I want to] remain sensitive to music and retain peace of mind. I fear if I become frivolous, I would damage my pure inspiration for music' (China Internet Information Centre 2004). He dislikes appearing on popular Chinese televised variety shows, and goes on concert tours as seldom as possible. When he does appear on a public engagement, he is always wearing a baseball cap, a habit one music journalist interpreted as 'a conscious effort to separate his private self to that of Dao Lang the public figure' (Xin 2012).

While Dao Lang's private, solitary personality stands at odds with the lively and uninhibited performances that characterise Uyghur social activities and life cycle rituals (Smith Finley 2013a, p. 98), it is apparently his love of solitary places that draws him to the north-western borderlands. The notion of loner is communicated through a series of photo shots of Dao Lang sitting or walking alone in sand dunes or desert ruins with just a guitar for company. This love of harsh and lonely terrain has proved the inspiration for several of his original compositions, such as 'The Poplars of Kashgar' (喀什噶尔胡杨 Kashenge'er huyang). The artist claims to have taken almost three years to write this song, which is based on the

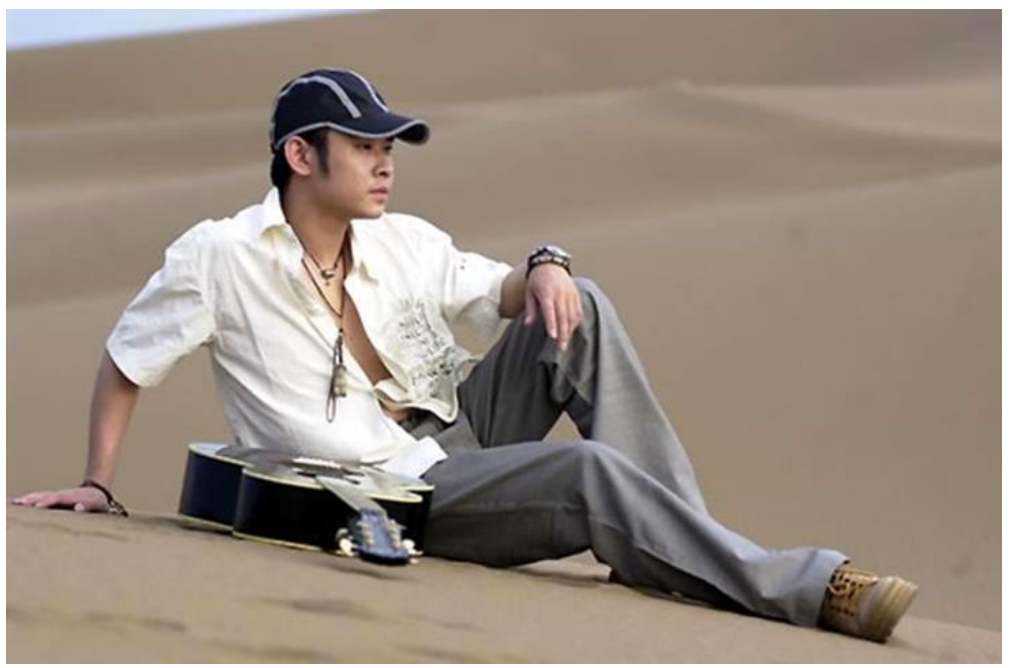

Photo: http://www.daolang.sg/index.cfm?GPID=79 

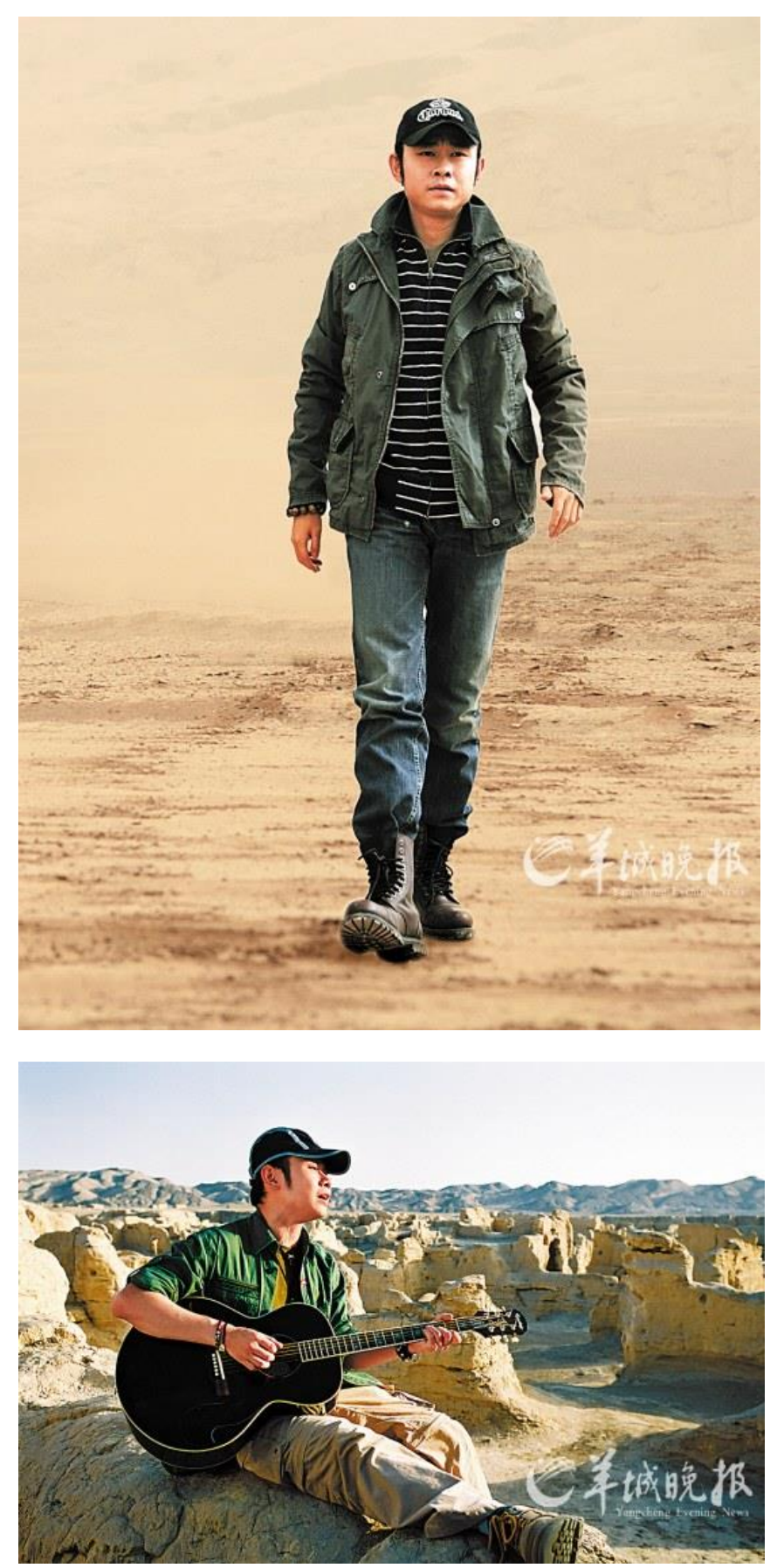

Photos reproduced with the permission of Yangcheng wanbao (Yangcheng Evening News, 2011)

powerful emotions he experienced in that oasis. During a recent press conference in San Francisco, Dao Lang explains:

To a man, Kashgar is a very tough place to be in. I was there, and I had said before, this place makes a man [...] Desert, Gobi, poplar trees, only poplar trees could grow there for one thousand years ... one thousand years without toppling over ... one thousand years without decaying [...] After seeing it, from many photos, so strange, 
that distorted form. In that distorted state, I believe many men could have been through that experience, that very painful stage in their growing up. That type of pain and suffering is just like the poplar tree, even when distorted, even when in pain, even when the soil is poor, without water, it still grows, it will grow. So I say that place makes a man (Baidu 2013).

The song proved so affective for the singer that, when his record company asked him to change the song's title on the grounds that the four characters (喀什噶尔 Kashenge'er) were strange and hard to pronounce, he refused, stating that without that title the song would lose its meaning: 'it refers to a special place' (Baidu 2013). His response suggests a reverence for the land that is almost religious, an idea that re-emerges again later:

Besides promoting Xinjiang's song and dance, there is also the sunshine of Xinjiang, just like here [San Francisco], similar, just like the same God's hand touching you [...] That one is a beauty without makeup' (Baidu 2013).

In 2013, the singer signalled his intention to retreat again, once he had completed tours of China, the USA and Canada (his first live performances for 5 years). Stating that he was 'not a terribly confident person, more of the introverted type', he spoke of needing $4-5$ years to write new material: 'I am not very suitable for the entertainment world, with my type of personality, so I don't come out to “dance” often' (Baidu 2013).

\section{Contesting Place: the rock fusion of Dao Lang}

So, how does the rock fusion of Dao Lang convey particular notions of space, place and identity? Frith (1996) identified four conventions in the production of popular music, including: sound (what you hear); performance (what you see); packaging (how music is sold); and the music's embodied values (ideology). In terms of sound, Dao Lang has drawn on the 'exotic' sonic qualities of traditional Uyghur music to infuse both his rearrangements of regional folk songs collected by Han song collector Wang Luobin, ${ }^{5}$ and his own compositions, including soft rock ballads and rock-style re-workings of Chinese revolutionary classics; both feature Uyghur instrumental backing (cf. Harris 2005b, p. 632). This mixing of popular soft rock with the 'ancient sounds of Xinjiang' has, in the eyes of some fans, created 'spectacular results' for Chinese Pop (Anon. 2011).

While much has been made of Dao Lang's initial rise to popularity, described as taking place 'out of the blue', and without any packaging or promotion (China Internet Information Centre 2004; Xiao, Shi and Chen 2011), a marketing strategy seems to have been in evidence from quite early on in his career. In 2003, the record company that produced Dao Lang's second album, Turkestan Lovesongs, asked him to assume a name from within the minority community. At that time, the singer suggested several possibilities (including Maigaiti, Abdulraj and Awati), but these were all vetoed by the company. Finally it was agreed to select the ethnonym 'Dolan' (Dao Lang 刀郎), because this translated into 'swordsman' in Chinese, better fitting the imagination that [Han] people have of the western borderlands 
(Zhang 2011). In this way, a local ethnonym - and important cultural symbol - was appropriated in the construction of an artistic identity for a Han incomer, and an entrenched stereotype of the sword-wielding nomad barbarian was reproduced (cf. Abramson 2003).

If we examine some of the packaging of Dao Lang's albums, a metaphor of domination and subordination quickly emerges in the descriptive text. The cover of his $2004 \mathrm{CD}$ release, titled Searching for Maira (寻找玛依拉 Xunzhao Mayila) announces Dao Lang as 'the mysterious singer who conquered (zhengfu) the Western regions'. The credits attribute the regional folk song 'In That Far-away Place' (Zai na yaoyuan de difang), to song collector Wang Luobin, the words and/or music of four tracks to Dao Lang, and five further tracks to other musicians, including some Han and some minority artists. Three tracks feature accompaniment by these minority artists on matouqin (Morin Quur, a Mongolian stringed instrument) or violin. Yet they do not appear on the cover of Searching for Maira; nor do they feature in the artwork on any other of the singer's CD releases; the indigenous peoples of the region are essentially rendered invisible. The images we see instead are of an apparently uninhabited territory, a pristine virgin land, where the sun rises and sets over snowy mountains, and an eagle soars over the deserted ruins of Gaochang / Qocho (the ancient Buddhist kingdom of the Uyghurs in Turpan): in short, terra nullius. ${ }^{6}$ Alternatively, we see the lone figure of Dao Lang himself, set against a backdrop of sands, desert rocks or Autumn poplars: one Han 'conqueror' sitting alone in a landscape devoid of local inhabitants.

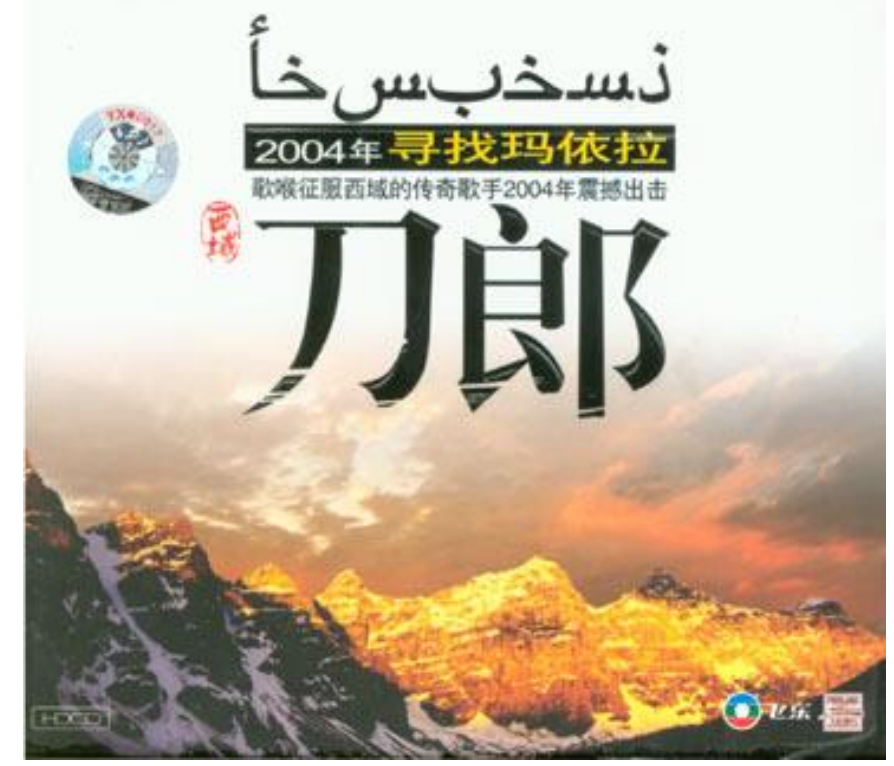

Cover of music CD, Searching for Maira (2004)

The notion of occupation of virgin land is suggested still more strongly in Dao Lang's rearrangement and delivery of the song 'In Praise of Xinjiang' (Xinjiang hao!). While the words to this song would express pride in the homeland, joy in the changing of its seasons, and hospitality towards visitors if sung by an indigenous person, they take on a quite different complexion when delivered by a Han in-migrant: 


\section{我们新疆好地方啊}

Women Xinjiang hao difang a

Our Xinjiang is a good place

\section{天山南北好牧场}

Tianshan nan bei hao shouchang

With good pastures north and south of the Tianshan [Heavenly Mountains]

\section{戈壁沙滩变良田}

Gebi shatan bian liangtian

The Gobi sands become fertile land

\section{积雪溶化灌农庄 \\ Jixue ronghua}

The snows melt and water the farmsteads

$$
[\ldots]
$$

来来来来...

Lai, lai, lai, lai

Come, come, come to...

我们美丽的田园

Women meili de tianyuan

Our beautiful pastures

\section{我们可爱的家乡 \\ Women ke'ai de jiaxiang \\ Our lovely homeland}

Uttered by a Han singer who migrated to the region from China proper just a few years before, the phrase 'our Xinjiang' (women Xinjiang) - often heard on the lips of Han residents of Ürümchi and other urban centres - acts to appropriate the region for Han incomers while dispossessing its original inhabitants. At the very least, it reconstructs the region as a multiethnic territory, which is 'home' to many different nationalities, regardless of time of arrival. Linguistic anthropologist, Arienne Dwyer, has shown how in the Chinese media, the new, non-ethnic identity Xinjiangren, expressed in the Chinese language, has been consciously promoted for all the inhabitants of the Northwest. This construction conceptually joins together Turkic speakers, Mongols, and others who consider themselves indigenous to the region with new migrants to Xinjiang: that is, Han Chinese and Hui (Dwyer 2005, pp. 30, 34). The term deliberately blurs ethnic distinctions, serving to reinforce the notion that Xinjiang is an 'inalienable' part of the PRC, and that any PRC nationality has a right to reside there. 
When Han people who have settled in the region call that place 'our Xinjiang', they are asserting ownership over the territory and articulating an equal sense of belonging. This is especially true for earlier generations of Han settlers, and for their children who were born and raised in Xinjiang. According to Rudelson and Jankowiak (2004, p. 306): 'Many [...] Hans truly committed themselves to making a better life in Xinjiang and have come to see themselves as "Xinjiang people" [Xinjiangren]. Hans who have lived in Xinjiang for decades insist that they are very different from the Hans in China proper'.

The song continues:

\section{麦穗金黄稻花香啊}

Maisui jinhuang daohua xiang a

Golden spikes of wheat, fragrant rice flowers, ah

风吹草低见牛羊

Feng chui caodi jianniu yang

Cows and sheep graze the wind-blown grasslands

葡萄瓜果甜又甜

Putao gua guo tian you tian

Grapes and melons, fruits sweet so sweet

煤铁金银遍地藏

Mei tie jin yin biandi cang

Coal, iron, gold, silver hidden in the ground

\section{$[\ldots]$}

来来来来...

Lai, lai, lai, lai

Come, come, come to...

我们美丽的田园

Women meili de tianyuan

Our beautiful pastures

我们可爱的家乡

Women ke'ai de jiaxiang

Our lovely homeland 
Again, if sung by a member of an indigenous group, these lines could be interpreted as gratitude for the many fruits of the homeland, and joy in the region's self-sufficiency. However, when the same lines are delivered by a Han incomer - in Chinese - they cannot help but suggest the appropriation and exploitation of natural resources that rightly belong to others (at least from the perspective of those others). At the same time, the singer appears to be sending a clear message to other Han people in China proper that they too should hasten to claim their share in this rich and fertile land ('Come, come, come...').

\section{The legacy of Wang Luobin}

As mentioned above, Dao Lang has rearranged and produced modern rock adaptations of a number of traditional folk songs previously popularised by song collector Wang Luobin. Wang made a career out of collecting minority songs from the Northwest, re-arranging them, adding Chinese-language lyrics, and presenting them to Han audiences as 'Xinjiang folk songs' (Harris 2005a, p. 383-4). This was possible because such songs are passed down through unwritten oral transmission, and lack ties to any one local author (Harris 2005a, p. 389). Wang then proceeded in 1993 to copyright the songs he had collected, a move which apparently credited him with their authorship (Harris 2005a, p. 388). After Dao Lang recorded new cover versions of many of these songs, he was not surprisingly dubbed 'the Wang Luobin of the 21st century' (China Internet Information Centre 2004). This association has been problematic for him because, during the 1990s, a number of Uyghur musicologists and musicians, as well as prominent Han musicologists, accused Wang of 'stealing' the Uyghurs' songs. They declared, moreover, that Wang had an insufficient knowledge of minority customs, and that his Chinese-language lyrics misrepresented and devalued Turkic culture. The most prominent critic in this affair, the Uyghur intellectual Sidiq Haji Rozi, was later forced to seek asylum in the United States. Back in Xinjiang, however, Wang Luobin had become virtually 'unassailable' in official state discourse (Harris 2005a, pp. 388-9; 392; 394; 399).

As neatly observed by Harris, Wang's relationship with the peoples and musics of Xinjiang fully illuminates Han-minority relations, in particular, majority consumption of Otherness and the contestation of identity (2005a, p. 381). The ambiguities surrounding ownership of the songs and belonging to the region continue to surface within contemporary state discourses around the song collector. According to the Chinese government's web portal (China.org.cn), which I visited in 2011, Wang had never set foot in Xinjiang until 1949, and 'dug out' his first tune, The Girl from Daban City, from a Uyghur driver in Lanzhou after plying him with wine and cigarettes. After the lyrics were translated into Chinese, this stateendorsed web narrative continues, 'the first great Xinjiang folk song was born' (China Internet Information Centre 2006); reading this, one might almost think that the song did not exist until made linguistically accessible - and culturally acceptable - to a Han audience. An article on Wang Luobin in Beijing Review, first published in 1993 and updated in 2009, presents his career in equally ambiguous terms. Settling in Xinjiang in 1949 as an artist attached to the People's Liberation Army, it states, Wang remained in the region until his death in 1996. His arrival led to his creation of several hundred widely-loved folk songs; 
many of his masterpieces originate from folk songs in Xinjiang and the northwest; and many of his lyrics have gone beyond the borders of China to be cited as typical Chinese songs (Cui 1993, my emphasis). Perhaps the most astonishing assertion made by this particular writer is to describe In That Faraway Place as 'characterised by strong folk flavor and melody, and deep feeling [...] loved and sung by successive generations since it was created in 1939' (Cui 1993, my emphasis). Perhaps it is only fitting, then, that most photographs of this 'Father of Northwest Chinese folk', as he is affectionately known, show him replete in cowboy hat, a representation entirely consistent with the Han goal of 'civilising' China's Wild West (cf. Sines 2002). Despite his insufficient knowledge of copyright law (which, to be fair, constituted a widespread problem in China through the 1980s and 1990s), Wang himself seems to have adopted a more realistic position in relation to his work. Describing how an elderly female fan in Singapore once gave him a pendant inscribed with the words 'Conveyor of Songs', he remarked: 'I liked that title. I have never regarded myself as a famous composer of lyrics. "Conveyor of Songs" suits me best' (Cui 1993).

Although Dao Lang's appraisal of the song theft saga is quite generous, Wang's case has created a legacy of mistrust within the local community of Uyghur musicians and intellectuals, and this continues to cause problems for Dao Lang's artistic aims in the present. Speaking to the press in San Francisco in 2013, Dao Lang stated that he regretted not meeting Wang Luobin before his death, and praised his achievements in re-arranging Xinjiang music to make it accessible to the Han people. However, the artist also acknowledged the difficulties he had inherited as a result of the controversy around Wang's work:

It could be that copyrights were then not very clear [...] Wang had always thought of himself as a person who passed down songs, but people erroneously assumed the songs were his original compositions. This created some misunderstandings between local Xinjiang minority musicians and Han musicians. Inevitably, this poses the biggest problem for us when we are promoting Xinjiang [...] we have the best melodies in Asia, actually in Central Asia. We all know that the centripetal force of Xinjiang music lies in Central Asia; it is from there that this musical style is inherited. There is no dispute as to what type of music the Han people like - they like melodies. From this angle, there are no contradictions in Xinjiang music, no problems of communication. But we need to identify a platform on which to communicate on the basis of national cultural identity, and a national musical language (minzu wenhua de rentong he yige minzu de yinyue yuyan (Baidu 2013).

It is not clear from the original interview transcript in Chinese whether Dao Lang here refers to national culture and identity at the level of the PRC (the multi-ethnic Chinese nation), thus means to encourage the harmonious merging of Han and minority music cultures; or whether he refers to national culture and identity at the level of the minority nationality (the Uyghur ethnic group), thus means to highlight the importance of engaging with local music and culture on the terms set by local people. He uses the ambiguous term minzu in Chinese, which 
can refer either to the Chinese nation or to a minority group in China, depending on the context in which it is used.

Certainly, there is a significant appetite in the cities of China proper for new music fusions that successfully combine traditional folk material from China's peripheries with modern music genres and instrumentation. At the start of 2007, The Wire carried a fascinating article recounting a singular performance by eight itinerant musicians from Kashgar prefecture, which took place under the banner of 'The Soul of Dolan' in November 2006. According to the enthusiastic reporter, the ensemble played 'an ecstatic groove of splintered serialist trance ... topped with qawwali-style chants and devotional declamations with an interplanetary twirling dance' (Barker 2007).

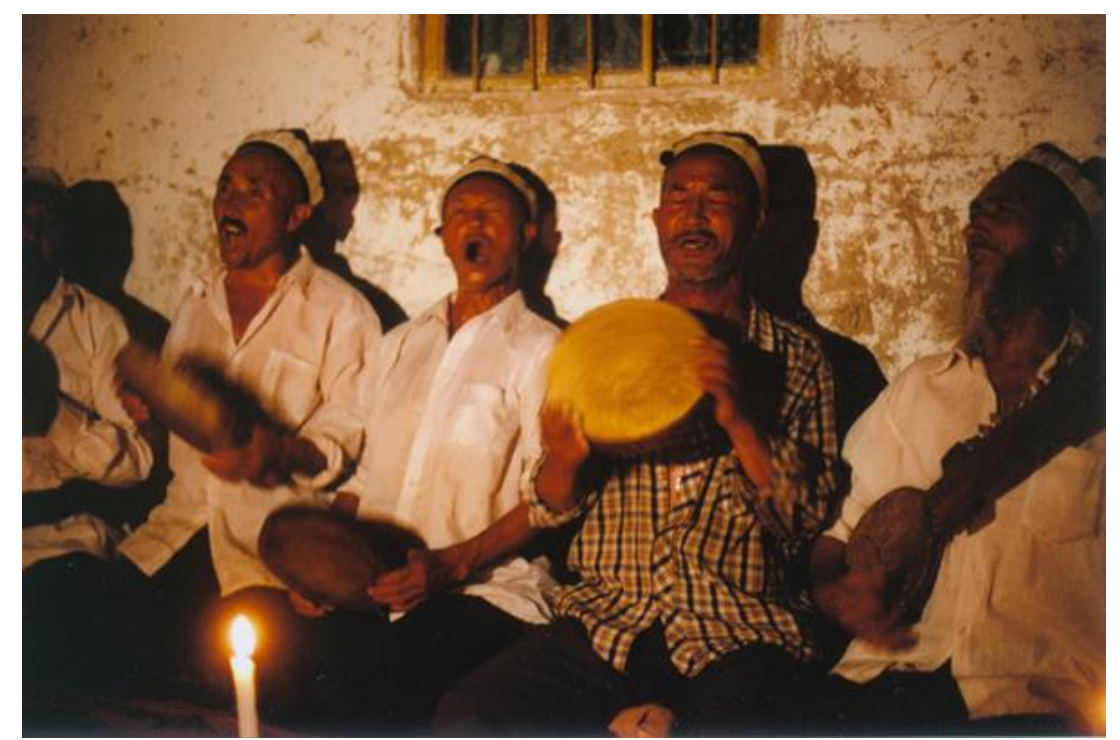

The Soul of Dolan. Photo: http://worldmusicshanghai.com/en/history/2012/show.asp?ID=207

Sitting in with them was Mamer, a Beijing-based musician with folk group Iz (Traces), who hails originally from northern Xinjiang. ${ }^{7}$ A regular at Nameless Highlands, an outlaw bar situated on the capital's north fourth ring road, he is said to have played a 'liquid, hypnotic guitar intro before being suddenly swamped by the full ensemble' (Barker 2007). For other examples, we need look no further than Beijing-based Uyghur artists, Äskär (rock fusion) and Arken Abdulla (new flamenco fusion) (Baranovitch 2007). However, while such fusions may be well received by Han and foreign audiences in China proper, regardless of the ethnic background of the artists who deliver them (minority or Han), the dynamics of their reception among audiences in Xinjiang are more nuanced. I shall return to this point later.

\section{Gendering of regional and national spaces}

Popular music is a central means both for the framing of discourses of national culture and identity and for the expression of discourses of gender, and the gendering of place (Bennett 2004, p. 6). In the context of appropriation of folk music from Xinjiang by (Han) 'outsiders' to the region, the two processes are achieved simultaneously: the indigenous peoples of Xinjiang are rendered subaltern to China's ethnic Han majority, even as Xinjiang the territory 
is gendered female and subordinate through the voyeuristic gaze on the minority female (cf. Gladney 1994). As Harris points out, local accusations against Wang Luobin of appropriation, exploitation and misrepresentation of Xinjiang regional culture imply a sense of collective Uyghur ownership, not only of a musical tradition but also of Uyghur women's bodies (2005a, p. 395) - a reaction to his perennial selection of songs relating to women, girls, love and flirtation. This focus on minority women similarly pervades many of Dao Lang's releases, including both cover versions and original compositions; see, for example, 'New Awarguli' (Awargül is a female given name in Uyghur; the lyrics tell of the 'beautiful eyes' of an 'intimate friend' who 'took my heart' and was lost in far-away Yili [Ghulja]); 'Big Eyes' (Da yanjing; the male protagonist speaks of 'your big eyes oh so pretty', claims he 'dares not look at you', and describes how his 'desire is set on fire' as he 'hungers for you'); and 'In that Faraway Place' (about a handsome girl, tantalisingly concealed in a yurt in a distant place). It is significant that the inspiration for his first massive hit single 'The First Snows of 2002' was triggered by the vision of a minority female. As recounted by Dao Lang in interview:

One evening in the early winter in 2002 , as I was stepping out of my studio, snowflakes were flying about and on the streets people were excitedly exclaiming: 'This is the first snow of 2002!' A Uyghur girl in a long bright red skirt was waiting at the bus stop and, together with the aroma of barbequed mutton wafting out of the restaurant nearby, all these conjured a scene, and a tune sprang into my mind (cited in Zhang 2011).

However, perhaps the most revealing metaphor of the relationship between Xinjiang and China proper, between the Uyghurs and the Han, is found in the song 'Wolf in Sheepskin' (Pizhe yangpi de lang, 2006). On the surface at least, the focus of this song appears to be the hopeless pursuit of an unattainable romantic dream:

$[\ldots]$

你别担心

Ni bie danxin

Don't be afraid

我知道想要和你在一起并不容易

Wo zhidao xiangyao he ni zai yiqi bing bu rongyi

I know it's not easy to be with you

我们来自不同的天和地

Women lai zi bu tong de tian he di

We come from different worlds

你总是感觉和我一起是漫无边际阴冷的恐惧 
Ni zongshi ganjue he wo yiqi shi manwubianji yinleng de kongju

You always feel cold unease when you're with me

我真的好爱你

Wo zhen de hao ai ni

(But) I truly love you

我愿意改变自己

Wo yuanyi gaibian ziji

I'm willing to change

我愿意为你流浪在戈壁

Wo yuanyi wei ni liulang zai Gebi

I'm willing to drift across the Gobi

$[\ldots]$

我愿意为你背负一身羊皮

Wo yuanyi wei ni beifu yishen yangpi

For you, I'll wrap myself in sheepskin

只求你让我靠近

Zhi qiu ni rang wo kaojin

Just let me be close to you

$[\ldots]$

你是我的天使是我的梦想

Ni shi wo de tianshi, shi wo de mengxiang

You are my angel, my dream

我搂你在怀里装进我的身体

Wo lou ni zai huai li jiangjin wo de shenti

I draw you close to my body

让你我的血液交融在一起

Rang ni wo de xueye jiaorong zai yiqi

Let our blood fuse and flow as one

In 2013, a reporter named Zhang Jun, from the China Voices Broadcasting Station in the United States, asked Dao Lang what kind of emotional state he had been in when he wrote this song, enthusing: 'It's such a philosophical song [...] I could feel myself running on the 
grasslands and on the plateau, seemingly connecting with the same emotions as you' (Baidu 2013). Given the deep affect created by this song among his fans, Dao Lang's reply to this question was surprisingly mundane. He claimed that he had had 'no thoughts in his head' before beginning to write the song, and related a somewhat unconvincing tale about how he had overheard some men chatting while eating in a restaurant. One of them had evidently blurted out 'Hey, you're just a wolf in sheepskin' in the context of a man doing something illicit and being found out by his wife. According to the artist, he had found this exclamation 'meaningful' simply because he was on the point of composing a song (Baidu 2013).

Yet a close reading of the song words and the accompanying music video suggests otherwise. As Rudelson and Jankowiak note, 'Hans and Uyghurs practically never marry. This normative restriction can become a source of sexual tension and animosity for Han men whenever they confront the fact that the local population does not consider them suitable marriage partners' $(2004$, p. 311). This perception of 'forbidden fruit' has led to the flourishing of karaoke halls in Ürümchi, where Han males (usually businessmen, government officials and police officers) pay to be accompanied by a Uyghur 'hostess' (sanpei xiaojie); accompaniment in this context can mean anything from a girl drinking, smoking, singing and dancing with her Han client to allowing him to touch her breasts or, in rarer cases, take her to a hotel for sex (Smith Finley 2015, forthcoming). In this context, I suggest that it is not stretching the point too far to interpret 'Wolf in Sheepskin' as a sad and frustrated recognition of the current impossibility of inter-ethnic romance (and Uyghur-Han unity more broadly), and a desire that this situation will one day change. In the accompanying video, Dao Lang is filmed driving an expensive-looking four wheel drive (representing the relative affluence of Han males?) into the desert, where he proceeds to perch on a mountain top and break his heart over a distant female figure dressed in pure white. While this woman does not appear to be of obvious Uyghur descent (one may assume that the use of a Uyghur female in this film might have led to street demonstrations of the proportion seen following the publication of Sexual Customs in 1989, a book considered highly derogatory by China's Muslims), she is clearly a female of minority descent, having large eyes, reddish-brown hair and a high nose. She lingers at a tantalising distance, astride a pure white horse, as Dao Lang waits patiently by a campfire in the moonlight. Suddenly, the frame changes and she is wearing a black top with a multi-coloured skirt, and riding a black horse. As she approaches Dao Lang, he takes her horse by the reins and leads her away...the next shot is of the pair galloping together through the empty desert, she on the white steed and he on the black. Yet at the song's end, the woman is once more wearing white and, though she reaches for Dao Lang's hand, she ultimately withdraws it. This image alternates in a visual collage with a painting of an (apparently) Uyghur female. Given the part he plays in this video drama, it is then not coincidental that Dao Lang has subsequently acquired the label of 'Wolf of the Western regions' (Wang 2012). While Dao Lang's own loyalty to his Xinjiang-born Han wife seems beyond reproach, as read from the sentimental media coverage of his family life (see Zhang 2011; Xiao, Shi and Chen 2011), the song must have proved an instant point of identification for Han men in Xinjiang and China proper, who dream of possessing an exotic Uyghur female and of her bearing their beautiful, mixed-race children. Indeed, the ideas in the song 
and images in the video can be linked directly to contemporary social phenomena in Xinjiang. It is certainly 'not easy' (indeed, it is practically impossible) for a Han male to court a Uyghur female in the current climate of inter-ethnic conflict. Even were the political and socio-economic tensions that underlie the conflict removed, it would remain the case that Han and Uyghur persons 'come from different worlds', the former having a Confucian 'structure of relevance' (Eriksen 1993), while the latter's is based upon Islamic social laws. Some Han men have indeed been 'willing to change' and to 'wrap themselves in sheepskin' (that is, convert to Islam, at least in the area of dietary prescriptions), but Uyghur families have rarely agreed to the proposition (cf. Smith Finley 2013a, 2013b). In this context, the suggestion that Han and Uyghur blood 'fuse and flow as one' seems indeed an impossible dream.

\section{Dao Lang's rock fusion as 'civilising mission'}

So what do the Xinjiang regional media and Dao Lang's official biographer have to say about this artist and his work? Part 6 (Dao Lang the Man) of Di Hua's biography Who is Dao Lang? (Shui shi Dao Lang? 2004) includes a section entitled 'Never Leave Xinjiang' (Yongyuan libukai Xinjiang). Here the writer observes: 'He's not like some musicians who leave Xinjiang for a bigger creative space as soon as they get famous; Dao Lang is still in Xinjiang following a local lifestyle, eating big chunks of meat and taking large gulps of alcohol' (Di Hua 2004, p. 163). This presentation of Dao Lang's ability to 'do as the Romans do when in Rome' (ruxiang suisu) itself buys deeply into essentialist stereotypes of the region circulating in official media as well as among ordinary Han Chinese. In short, ethnic groups in Western China (Uyghurs and Tibetans) are routinely represented as 'savage' (yeman) and as following a predominantly meat-based diet (Smith Finley 2013a, p. 97). Like certain minority groups elsewhere in China, they are also characterised as being capable of consuming vast quantities of alcohol (cf. Blum 2001, pp. 124-25: on the Wa; Gladney 1994, p. 98: on the Mongols). Meanwhile, the subtitle for this section borrows the phrase libukai (inseparable; inextricably linked) from state discourses around the ideal of 'nationality unity'.

In the regional media, the concept of fusion (of musical, social and biological types) takes centre stage in feature articles on the Dao Lang phenomenon. The Ürümchi-based female journalist, Hou Fei, enthused in 2003:

Dao Lang absorbs Xinjiang culture just as if breathing in fresh air; he lives a Xinjiang lifestyle alongside the Xinjiang people [...] yet he is a southerner who only migrated to the region in the mid-90s [...] He has completely blended into (rongru 融入) Xinjiang. He studies Xinjiang folk music, and is learning to play tämbur with a Uyghur teacher. He has married an 'authentic' (zhengshi 正式) Xinjiang girl, who has borne him a 'local' (dichan 地产) Xinjiang baby...how can we say he is not a real Xinjiangren? Let's drink to our Dao Lang, our ethnic music, our Xinjiang!' (Hou 2003a).

Given that the writer chooses to place the words 'authentic' and 'local' in quote marks, the average reader might be forgiven for observing: 'The lady doth protest too much, methinks. ${ }^{98}$ 
In what sense has Dao Lang 'blended into' Xinjiang? To what extent does he live a Xinjiang lifestyle? Does he for example attend the Friday prayer at mosque, and eat only in halal restaurants? The reality, of course, is that Dao Lang lives alongside a particular sector of 'Xinjiang people', namely, Xinjiang Han, many of whom were once newcomers like himself. He may have tried to learn to play traditional Uyghur stringed instruments, but it is minority musicians who play on his recordings and these individuals are not pictured on his CD sleeves: this does not suggest collaboration on an equal footing. He has married a daughter of the previous generation of Han in-migrants, and she has given birth to an ethnic Han baby in Xinjiang. These are the rather tenuous grounds on which Hou Fei claims that Dao Lang has been absorbed into the local culture. She ends by proposing a toast to Dao Lang's regional credentials as a bona fide Xinjiangren, seemingly unaware of the growing trend among local Uyghurs to renounce alcohol and tobacco (since the early 2000s, see Smith Finley 2007).

Revealing her youthful inexperience in failing to acknowledge the contribution of Dao Lang's predecessor, ${ }^{9}$ Wang Luobin, Hou Fei writes in a second feature:

Covers of minority songs are a recent phenomenon on the Chinese music scene [...] Their fascination has to do with endowing old cultural elements with new strength, allowing audiences to find one voice within the familiar and the strange [...] in Xinjiang, the diversity of Central Asian culture gives this place the possibility of embracing all cultures; the mark of this diverse culture is its ability to fuse together' (Hou 2003b).

Her narrative implies that indigenous artists are stagnating in a somehow static 'old culture', while Han artists - such as Dao Lang - are needed to imbue that culture with new vigour; in other words, Han society (and language and music) is advancing and innovating, while minority societies (and languages and musics) are standing still. Han audiences are 'fascinated' by Dao Lang's music because his oral delivery in Chinese and musical rearrangements sanitise Xinjiang's cultural traditions and make them palatable to a Han audience. Meanwhile, Hou capitalises on the historically syncretic quality of Central Asian cultures and traditions by pointing out that, in that case, Xinjiang is fully able to embrace the Han culture too. In this way, the process of fusing Han and local musics comes to symbolise the fusion (dilution) of the Uyghur demographic in Xinjiang through Han in-migration, and the state's desired goal of their assimilation into China's 'great multi-ethnic family' (中国民 族大家庭 Zhongguo minzu da jiating). If language and culture constitute the symbolic boundaries of the global age (Morley and Robins1995: 1), then Dao Lang's music represents the permeability of the national limits - both Han and Uyghur.

Musing further on Dao Lang's treatment of traditional folk songs, Hou Fei goes on to suggest the superiority of Dao Lang's cover versions in relation to the local originals :

The oral transmission (Ch. chuanchang 传唱) of songs is very important in terms of creating positive publicity for the West: in the minds of Chinese in the 'interior' [Ch. 
kouli or Han Chinese in China proper], Xinjiang tunes signify humour, happiness, a clear rhythm, short sentences and a narrow musical range. But, when they hear Dao Lang's songs, they feel diversity and complexity' (Hou 2003b).

In a similar vein, she cites a Han internet poet (web identification: 'Xinjiang black horse') as follows: 'The songs covered by Dao Lang are old tunes, long familiar to our ears; and yet they are no longer those standard tunes. Dao Lang has fused them with elements of pop and rock music, and a slightly hoarse vocal. Without doubt, the ear is meeting with the romance of music' (Hou 2003b). It is interesting to compare their reductionist evaluations of the region's traditional songs with musicologist Rachel Harris's criticisms of Wang Luobin's cover versions: she argues that, in them, the complexity of Uyghur song is 'ironed out' and replaced with a 'stereotyped pseudo-exotic sound'; that the original asymmetric rhythms give way to a regular four-beat; that modality gives way to the pentatonic scale; and that the original 'elastic' vocal is replaced by the smooth nasal delivery associated with Chinese pop (Harris 2005a, pp. 396-7).

Hou Fei ends by lauding Dao Lang's ability to produce original compositions with a flavour that is more uniquely 'Xinjiang' than the indigenous songs that preceded them. Declaring that, since the mid-1990s, Xinjiang (by which she means Xinjiang-based Han) has also created 'some original popular tunes of its own', she writes:

Vocabulary such as desert, white poplar, fellow soldier, vineyard, black eyebrows, shared by all singers in Xinjiang, have been more deeply excavated by Dao Lang. Almost as if he brought the words back to life [...] Within the territory of Chinese music, the component of Western music will become ever greater; and this process is still going on (Hou 2003b, my emphasis).

Again, we have the sense that it is the fusing of traditional melodies and instrumentation with lyrics in the Chinese language that has injected local songs with new blood, and made them palatable to the Han audience. At the same time, the latent analogy between the growing importance of so-called 'Western music' in the national music sphere, and the increased incorporation of Xinjiang the territory into the Chinese nation, is unmistakable.

In rare interviews with Dao Lang himself, the notion of a Chinese civilising mission is less prominent but nonetheless present. Asked the origin of his unique musical style, the artist related how many had urged him not to cover Xinjiang folk songs on the grounds that they were 'unfashionable' (一点都不时尚 yidian dou bu shishang). His response was to set out to show them the value of Xinjiang music by bringing them an unexpected sound (fusion): 'Only in this way can you create a sense of belonging in an entire generation' (Xiao, Shi and Chen 2011). His explanation suggests less the singer's overt mission to promote Xinjiang to Han in China proper, and more a covert mission to embed a feeling of indigeneity into the psyche of the Xinjiang Han. Reflecting on the time he spent with the Dolan Uyghurs, the singer contrasts the rough and ready Dolan vocal with the sophistication of Chinese regional 
operatic styles: 'Many people say my voice is unique. The fact is, I have combined the bold and rough Uyghur music with the high pitch of Sichuan opera. The result is I have created something different' (China Internet Information Centre 2004). According to Han fans posting on an unofficial website, this voice 'melts countless hearts' (Anon. 2011). Dao Lang continues: 'When I was making Love Songs from the Great Desert [...] I thought a lot about the unsophisticated customs of the Uyghur people and also about the years when I was drifting. I thought about nature. The music flew into my soul, and tears flew out of my eyes' (China Internet Information Centre 2004). These thoughts chime with two prevalent stereotypes of minority groups circulating among Han Chinese: first, that they are simple and guileless (a quality little respected in Chinese culture); second, that they remain closely linked to the earth (in other words, most are subsistence farmers, thus are less developed or urbanised than Han).

\section{Dao Lang as 'Guardian of the Borderland'}

As noted by Bennett, the power that can be invested in music as a statement of identity has led to music becoming an instrument and expression of nationalism (2004, p. 5). If Dao Lang's personal intentions in 'promoting' Xinjiang are sincere, it must be said that his project embodies the perfect vehicle for the state to promote its (Han) nationalist agenda. The PRC leadership is, after all, no stranger to the cynical manipulation of music - folk and popular for political ends (cf. Perris 1985; Tuohy 2001; Ho \& Law 2012). While Dao Lang's music may originally have been born of a genuine desire to communicate the wild beauty of the Northwest to Han compatriots, it seems subsequently to have become an emblem for ethnic unity, national unification, and Chinese neo-patriotism. To give some examples: in 2007, Dao Lang sang 'In Memory of Fellow Soldiers' (Huainian zhanyou) at the 80th anniversary celebration of People's Liberation Army (PLA) Day, held in Ürümchi; note that the PLA, along with the Xinjiang Production and Construction Corps (XPCC, a para-military organisation), has constituted the key means of securitising the region since the "peaceful liberation' of Xinjiang in 1949. Also in 2007, Dao Lang performed his original song 'Honour' (Rongyu) at a state celebration of the completion of Beijing's Olympic Sports Stadium, a core symbol of Chinese national pride in recent years. New Year's Eve 2007 saw the artist in Beijing, welcoming in China's Olympic year with film director Zhang Yimou (once-criticnow-turned-patriot), pianist Lang Lang and actor Jackie Chan (Anon. 2008-2014). In 2008, Dao Lang performed 'In Praise of Xinjiang' (Xinjiang hao!) and an original composition 'On Erdaoqiao' (Guanyu Erdaoqiao) at the Xinjiang Spring Music Night, ${ }^{10}$ one of a series of annual, televised gala events held in celebration of the Chinese Spring Festival, and known for their ability to connect domestic space (the family) with national space (the Chinese nation), and then transnational space (the Chinese diaspora) (Sun 2007). In the same year, he released the compilation Red Classics, comprising rock versions of ten Chinese revolutionary songs, ${ }^{11}$ and contributed to the Olympic theme song 'Beijing Welcomes You'.

This process precisely mirrors the 'wheeling-out' of Dao Lang's predecessor, Wang Luobin, at numerous state occasions in the 1990s, and again in 2000, when Premier Jiang Zemin visited Xinjiang. As Harris put it, Wang's songs were 'perfect vehicles for promoting the 
state's preferred images of harmonious minority nationalities' (2005a, pp. 401-2). Compare this state-sanctioned media persona with Dao Lang's professed image of 'low-key' (didiao), reluctant superstar. In 2004, he had told his biographer: 'A pop star is a product you deliberately create and package, to be often displayed to others; I would rather people pay attention to my music' (Di 2004, p. 163).

\section{Conclusion: taking folksongs back to the folk?}

So: how far can Dao Lang be said, in the words of an independent Han musician from Xinjiang, to have 'taken folksongs back to the folk' (Hou 2003b)? Assuming that 'folk' here means the indigenous Uyghurs - that is, those who orally transmitted the songs from generation to generation over the decades - the statement barely sticks at all. One reason is that Dao Lang's core audience is Han, be they situated in Xinjiang, China proper or the diaspora. It was the Beijing Music Society, based in China proper, that voted him 'Best Pop Singer/Artist of the year' in 2002, making him only the second artist ever to receive the honour (the first was Chinese rock artist, Cui Jian, in 1987). Similarly, it was at the Fifth Chinese Music Media Awards that his 'innovative music style' earned him seven nominations in 2005 (Anon. 2008-2014). From 2004 on, after being signed to a five-year contract by Universal Music (China and Hong Kong), he stepped beyond PRC national boundaries to enter the international phase of his career (McClure 2004). The 2004 album, The First Snows of 2002, 'swept across Chinese communities around the world like a tornado...Dao Lang became the best known singer to the hundreds of millions of Chinese living in the diaspora, to whom he introduced an "ethnic wave"” (Wang 2012; cf. Xin 2012; Baidu 2013).

Dao Lang's biographer claims that Ürümchi residents treat Dao Lang as if he had 'brought honour to the family' ('family' here meaning the community of Xinjiang Han) (Di 2004, p. 165). Commenting that while people recognise the singer on the street, he is rarely bothered or surrounded by anyone, Di attributes this to local people's love for the artist and respect for his creative space (2004, p. 167). Perhaps, however, it is because Dao Lang's core audience is not in Xinjiang, where Han constitute less than 40 per cent of the regional population and number just eight and a half million persons, but in China proper and the diaspora. For one thing, first- and second-generation Han settlers in Xinjiang have been known to scoff at Dao Lang's 'ethnic music', being well acquainted with the authentic product. For another thing, bilingual Uyghur youth in the regional capital prefer to listen to Chinese-language songs performed by native Uyghur (not migrant Han) artists.

The second reason why Dao Lang has not succeeded in 'taking folksongs back to the folk' is that, like Wang Luobin before him, he has aroused the ire of Xinjiang's indigenous artists. Consider the following excerpt from a 2012 interview with Beijing-based Uyghur flamenco fusion artist, Arken Abdulla:

'Dolan' is a musical form, a cultural form on a par with Beijing opera; it is a piece of cultural heritage. Dolan music has nine suites; there is also Dolan art; and Dolan is an 
ethnonym. I grew up in the Dolan region, but I wouldn't dare to casually assume the artistic name 'Dolan', or haphazardly alter Dolan folk songs. Because I believe that this [cultural heritage] is the very essence of an ethnic group as it is handed down. You cannot appropriate it blindly (Kang 2012).

Tangible in his words is a sense of incredulity at the idea that an 'outsider', who is not conversant in the local language, and is unfamiliar with the complexities of the local culture, might presume to adopt the local ethnonym and proceed to make music under that banner. Arken continues: 'The singer Dao Lang has no connection whatsoever with real Dolan music' (Kang 2012).

Music can become an especially strong marker of national pride and identity during times of war or internal socio-economic crisis (Bennett 2004, p. 5). Following the tragic ethnic riots in Ürümchi in 2009, a group of artists in Xinjiang called upon Dao Lang and other well-known musicians to launch a music movement as an 'alternative antidote for the injured, the bereaved and the bewildered soul' (Anon. 2008-2014). Within four days, Dao Lang had written and recorded the song 'One Family' (Yi jia ren) together with the Uyghur chairman of the regional music association, Nusrat Wajdin. The lyrics proclaimed: 'Home is where we are; where we are is Greater China; we're one family, you and me; together through all odds'. In a statement, the artist observed: 'The $5^{\text {th }}$ July riot jolted us awake to the importance of unity; we shall use our music to denounce separatism' (Anon. 2008-2014). He continued:

I've lived in Xinjiang for the past 14 years and have seen with my own eyes the progress made [...] I wish to do my best as a responsible artist, to propose that artists from all ethnic groups get together to write songs on harmony and friendship, as a way to unite Xinjiang (Anon. 2008-2014).

Dao Lang was subsequently spotted on Chinese Central Television meeting then President Hu Jintao during his August 2009 inspection tour of Xinjiang. During the visit, Hu urged residents of Xinjiang to focus on reform and development as well as ethnic unity and stability. Dao Lang's presence is consistent with his contribution to a stream of prounification songs that celebrated the 'great family of Chinese nationalities'. One of these, 'China, We Are Your Children', was then being broadcast on local television throughout the day. It was cordially received by President $\mathrm{Hu}$ Jintao, and subsequently selected as 'a modern representation of ethnic unity in Xinjiang' (Wang 2012).

After several months of silence, during which Dao Lang tried - and failed - to put behind him the tragic events of 2009, the artist announced in an online video message in March 2010 that he had decided to leave Xinjiang. A note on the unofficial fan website informed fans that, as of April 2010, Dao Lang has a second home and recording studio in Beijing (Anon. 20082014). When Dao Lang spoke again, it was to state: 
Xinjiang has given me a new lease of life in music. It is a place that I will not forsake. I may be physically in Beijing, but my heart has never for a moment left Xinjiang. We still have a house there, and many friends too. There is also the great Gobi that excites me. Xinjiang is the home of my soul. I will never leave that place (Zhang 2011).

His words echo those of Wang Luobin, who, when asked whether he would bid farewell to his home in Ürümchi to obtain 'a better lifestyle' in China proper, replied: 'My melodies stem from Xinjiang. They have helped me survive difficult times and I cannot pull myself away' (Cui 1993). In reality, however, Dao Lang has rarely returned to Xinjiang to perform since relocating to Beijing. On 11 September 2010, just over a year after the fatal riots, he travelled to Shihezi, a city in northern Xinjiang with a 95 per cent Han population, at the request of the Cultural Bureau, in order to 'put up a show of support' for its residents. This event perhaps especially underlines the role played by his music in the articulation of the community and collective identity of the Xinjiang Han: an identity grounded in certain physically demarcated and 'safe' urban spaces (cf. Bennett 2004, p. 3). He also delivered a solo concert - the first of its kind in Xinjiang - held at the Xinjiang Sports Stadium on 20 December 2012. According to journalists publicising the event in advance, Dao Lang was scheduled to return to 'that piece of land with which he is deeply in love, and to which he has given his soul'; meanwhile, the concert would dedicate 'songs with Xinjiang characteristics and Dao Lang style' to people of all ethnic groups, and demonstrate the singer's true feelings towards that 'hot piece of earth' (Wang 2012).

The violence that consumed Ürümchi in 2009 has had the effect of 'scaring some Hans out of their westward adventure' (Rudelson \& Jankowiak 2004, p. 310). Yet, as Massey highlights, identities are multiple and constructed in relation to multiple locations (1993, p. 65). Like most Han migrants to Xinjiang, Dao Lang has all along retained strong links to his native place: Zizhong county, Sichuan. In February 2008, he attended a three-day primary school reunion there, arranged by a former classmate and good friend. Then, when a deadly earthquake struck his hometown on 12th May 2008, the artist made a donation of 100,000 Chinese yuan to the Xinjiang branch of the Red Cross under the name of Luo Lin (Anon. 2008-2014). Dao Lang's withdrawal to the Chinese capital is symbolic both of the fragility of ethnic unity and ethnic harmony in the Northwest and of the government rhetoric that celebrates it. His attempt to 'author space' through the fusion of Han and Uyghur musical styles, and the visual superimposition of his figure on the desert landscape is, for the time being, thwarted; he has failed to 'tell a particular story about the local' (Bennett 2004, p. 3). At the same time, the state project of cultural imperialism has been disempowered in its ongoing attempt to speak for and represent the ethnic Others of the Northwest.

\section{List of References}

Abramson, Marc S 2003, 'Deep Eyes and High Noses: Physiognomy and the Depiction of Barbarians in Tang China', in Nicola Di Cosmo \& Don Wyatt (eds), Political Frontiers, 
Ethnic Boundaries and Human Geographies in Chinese History, Routledge Curzon, London, pp. 119-59.

Allworth, Edward \& Gulamettin, Pahta 1988, 'A Gentle, New Allegory by an Older Uyghur Author', Doghu Türkistan'in Sesi, vol. 5, no. 7, pp. 19-20.

Anon. 2011, 'Introduction: Who is Dao Lang?', Unofficial fan website, viewed 17 March 2011, http://www.daolang.sg/index.cfm?GPID=79.

Anon. 2008-2014, 'Dao Lang: Latest News', Unofficial fan website, viewed 17 March 2011, http://www.daolang.sg/index.cfm?GPID=6; http://www.daolang.sg/index.cfm?GPID=31; http://www.daolang.sg/index.cfm?GPID=60.

Baidu 2013, 'Dao Lang 2013 Jiujinshan xunyan fabuhui xianchang (Dao Lang's 2013 Press Conference in San Francisco)', viewed 25 June 2014, http://tieba.baidu.com/p/2387985739.

Baranovitch, Nimrod 2007, 'From Resistance to Adaptation: Uyghur Popular Music and Changing Attitudes among Uyghur Youth', The China Journal, vol. 58, pp. 59-82.

Barker, Steve 2007, 'Global Ear, Beijing: Traditional and Contemporary Styles Collide Comfortably in Beijing's Scattered Underground', On The Wire, BBC News, issue. 275, Rewind 2006.

Bellér Hann, Ildikó 2008, Community Matters in Xinjiang, 1880-1949: Towards a Historical Anthropology of the Uyghur, Brill Academic Publishers, Leiden.

Bellér-Hann, Ildikó, Cesàro, M. Cristina, Harris, Rachel \& Smith Finley, Joanne 2007, 'Introduction', in Bellér-Hann, Ildikó, Cesàro, M. Cristina, Harris, Rachel \& Smith Finley, Joanne (eds), Situating the Uyghurs between China and Central Asia, Ashgate, Aldershot.

Bennett, Andy 2004, 'Music, Space and Place', in Sheila Whiteley, Andy Bennett \& Stan Hawkins (eds), Music, Space and Place: Popular Music and Cultural Identity, Ashgate, Aldershot, pp. 2-8.

Bequelin, Nicholas 2004, 'Criminalizing Ethnicity: Political Repression in Xinjiang', China Rights Forum, vol. 1, pp. 39-46.

Blum, Susan D. 2001, Portraits of "Primitives": Ordering Human Kinds in the Chinese Nation, Rowman and Littlefield, Lanham, MD.

China Central Television 2009, 'President Hu: Efforts still needed to promote Xinjiang's economic development', CCTV International, Broadcast on 26 August, viewed 2 October 2011, http://english.cctv.com/program/worldwidewatch/20090826/101520.shtml.

China Internet Information Centre 2006, 'Wang Luobin - Father of Folk', China.org, viewed 23 March 2011, http://www.china.org.cn/english/NM-e/166870.htm.

2004, 'Dao Lang: I'm an Ascetic for Music', China.org, 25 June, viewed 17 March 2011, http://www.china.org.cn/english/NM-e/99330.htm. 
Cui, Lili 1993, updated, 'Wang Luobin and His Songs', Beijing Review, no. 30, updated 19 May 2009, viewed 20 June 2014, http://www.bjreview.com.cn/special/200905/19/content_196462.htm\#.

Di, Hua 2004, Shei shi Dao Lang? Dui Dao Lang shenshi, aiqing, jingli, shenghuo de wanquan jiemi pilu Xiyu gewang chengming beihou buweirenzhi de gushi (Who is Dao Lang? The unknown story of the Western Region Song King's life, loves, experiences and rise to fame), Shanghai Academy of Social Sciences Publishing House, Shanghai.

Dwyer, Arienne M 2005, The Xinjiang Conflict: Uyghur Identity, Language Policy and Political Discourse, Policy Studies 15, East-West Center, Washington.

Eriksen, Thomas H. 1993, Ethnicity and Nationalism: Anthropological Perspectives, Pluto Press London.

Frith, Simon 1996, Performing Rites: On the Value of Popular Music, Harvard University Press, Cambridge, MA.

Geng, Shimin 1984, 'On the Fusion of Nationalities in the Tarim Basin and the Formation of the Modern Uighur Nationality', Central Asian Survey, vol. 3, no. 4, pp. 1-14.

Gladney, Dru C 1994, 'Representing Nationality in China: Refiguring Majority/ Minority Identities', Journal of Asian Studies, vol. 53, no. 1, pp. 92-123.

Harrell, Stevan 1994, 'Introduction: civilizing projects and the reaction to them', in Stevan Harrell (ed.), Cultural Encounters on China's Ethnic Frontiers, Hong Kong University Press, Hong Kong, pp. 3-36.

Harris, Rachel 2005a, 'Wang Luobin: Folk Song King of the Northwest or Song Thief?', Modern China, vol. 31, no. 3, pp. 381-408.

2005b, 'Reggae on the Silk Road: The Globalization of Uyghur Pop', China Quarterly, vol. 183, no. 1, pp. 627-43.

2002, 'Cassettes, Bazaars, and Saving the Nation: The Uyghur Music Industry in Xinjiang, China', in Timothy Craig \& Richard King (eds), Global Goes Local: Popular Culture in Asia, University of British Columbia Press, Vancouver and Toronto, pp. 265-82.

Ho, Wai-Chung \& Law, Wing-Wah 2012, 'The Cultural Politics of Introducing Popular Music into China's Music Education', Popular Music and Society, vol. 35, no. 3, pp. 399425.

Hou, Fei 2003a, 'Wo shi yige “xin Xinjiangren” (I am a new Xinjiangese)', Xinjiang dushibao (Xinjiang Daily), 27 October. 
Hou, Fei 2003b, “Xiyu qingge” wei shenme huo? Dao Lang xianxiang huoqi you yin. (Why is Turkestan Lovesongs such hot property? There's a reason why the Dao Lang phenomenon caught fire.)', Xinjiang dushibao (Xinjiang Daily), 16 December.

Kang, Fei 2012, 'Arken: I think you shouldn't abuse the word "Dolan", Xin jing bao (Beijing News), 31 May, viewed 28 June 2014, http://ent.ifeng.com/zz/detail_2012_05/31/14930506_0.shtml?_from_ralated.

Massey, D 1993, 'Power-Geometry and a Progressive Sense of Place', in B Bird, B Curtis, T Putnam, G Robertson \& L Tickner (eds), Mapping the Futures: Local Cultures, Global Change, Routledge, London.

McClure, Steve 2004, 'Asian Talents Make Big Strides', Billboard magazine, 25 December 2004, YE-13.

Milgram, B Lynne 2005, 'Edgy Things: Negotiating Borders and Identity in Asian Material Culture', Asian Studies Review, vol. 29, pp. 231-32.

Millward, James A. 2007, Eurasian Crossroads: A History of Xinjiang, Hurst, London.

Morley, David \& Robins, Kevin 1995, Spaces of Identity: Global Media, Electronic Landscapes and Cultural Boundaries, Routledge, London.

National Bureau of Statistics of China 2011, Communiqué of the National Bureau of Statistics of People's Republic of China on Major Figures of the 2010 Population Census (No. 1), April 28, viewed 25 June 2014, http://web.archive.org/web/20131108022004/http:/www.stats.gov.cn/english/newsandcoming events/t20110428_402722244.htm.

Perris, Arnold 1985, Music as Propaganda: Art to Persuade, Art to Control, Greenwood Press, Westport, Connecticut.

Rudelson, Justin \& Jankowiak, William 2004, 'Acculturation and Resistance: Xinjiang Identities in Flux', in S Frederick Starr (ed.), Xinjiang: China's Muslim Borderland, ME Sharpe, Armonk, New York, pp. 299-319.

Sines, Abigail 2002, 'Civilizing the Middle Kingdom's Wild West', Central Asian Survey, vol. 21, no. 1, pp. 5-18.

Smith, Joanne N 2007, 'The Quest for National Unity in Uyghur Popular Song: Barren Chickens, Stray Dogs, Fake Immortals and Thieves', in Ian Biddle \& Vanessa Knights (eds), Music, National Identity and the Politics of Location: Between the Global and the Local, Ashgate, Aldershot, pp. 115-42.

Smith Finley, Joanne (2015, forthcoming), 'Education, Religion and Identity among Uyghur Hostesses in Ürümchi', in J Smith Finley \& X Zang (eds), Language, Education and Uyghur Identity in Urban Xinjiang, Routledge, London. 
2013a, The Art of Symbolic Resistance: Uyghur Identities and Uyghur-Han Relations in Contemporary Xinjiang, Brill Academic Publishing, Leiden.

2013b, 'Contesting Harmony in TV Drama: Ethnic Intermarriage in Xinjiang Girls', in I Bellér-Hann \& T Brox (eds), On the Fringes of the Harmonious Society:

Tibetans and Uyghurs in Socialist China, Nordic Institute of Asian Studies Press, Copenhagen, pp. 263-92.

Sun, Wanning 2007, 'Dancing with Chains: Significant Moments on China Central Television', International Journal of Cultural Studies, vol. 10, no. 2, pp. 187-204.

Toops, Stanley 2004, 'The Demography of Xinjiang', in S Frederick Starr (ed.), Xinjiang: China's Muslim Borderland, ME Sharpe, Armonk, New York, pp. 241-63.

Tuohy, Sue 2001, 'The Sonic Dimensions of Nationalism in Modern China: Musical Representation and Transformation', Ethnomusicology, vol. 45, no. 1, pp. 107-31.

Wang, Lixiong 2007, Wo de Xiyu, ni de Dongtu (My West China; Your East Turkestan), Locus Publishing, Taiwan.

Wang, Xiaohua 2012, 'Dao Lang xiexie ni xunhui yanchanghui jijiang jiqing shangyan (Dao Lang's "Thank You" return concert will take to the stage with passion)', Xin Si Lu (New Silk Road), viewed 20 June 2014, http://news.xj163.cn/news/2012-09/26/content_2336759.htm.

Xiao, Zhiying; Shi, Xisheng; and Chen, Jianwei 2011, 'Dao Lang: Yiye chengming hold bu $z h u$ (Dao Lang: I couldn't cope with becoming famous overnight)', Yangcheng wanbao (Yangcheng Evening News), 16 September, viewed 28 June 2014, http://ycwb.com/epaper/ycwb/html/2011-09/16/content_1211680.htm.

Xin, Jie (ed) 2012, 'Yu Dao Lang yixi zhi tan (In Conversation with Dao Lang)', Interview conducted in Ürümchi following Dao Lang’s 2012 concert, 21 December, trans. Quek Sai Kee, viewed 25 June 2014, http://www.daolang.sg/index.cfm?GPID=101.

Zhang, Haifeng 2011, 'Xibu qingge wang, Dao Lang: yingdang gei jiaren kuaile (Western Lovesong King, Dao Lang: You Should Make Your Family Happy)', Home Magazine, 9 December, http://blog.sina.com.cn/s/blog_72254458010124gt.html.

\section{Discography}

Alim, Ömärjan 1995, Qaldi Iz (Traces), Music Cassette, Minzu chubanshe, Ürümchi. CNM06-95-0002-0.

Dao Lang 2001, Damo qingge (Love Songs from the Great Desert), CD, Ayalasuo yinyue wenhua fazhan youxian gongsi, Beijing.

Dao Lang 2003, Xiyu qingge (Turkestan Love Songs), CD, Tianjin yinxiang gongsi, Tianjin, ISRC: CN-C09-03-305-00/A.J6. 
Dao Lang 2004, 2002 Nian diyi chang xue (The First Snows of 2002), CD, Tianjin yinxiang gongsi, Tianjin, ISRC: CN-C09-03-308-00/A.J6.

Dao Lang 2004, Xunzhao Mayila (Searching for Maira), CD, Minzu yinxiang chubanshe, Beijing, ISRC: CN-M06-04-354-00/A.J6.

Dao Lang 2005, Kashenge'er huyang (The Poplars of Kashgar), CD, Guangzhou yinxiang chubanshe, Guangzhou, ISRC: CN-F28-04-466-00/A.J6.

Dao Lang 2006, Pizhe yangpi de lang (Wolf in Sheepskin), CD, Nei menggu wenhua yinxiang chubanshe, Hohhot, ISRC: CNC180634100.

\footnotetext{
${ }^{1}$ Statistical Bureau of the Xinjiang Uyghur Autonomous Region, Xinjiang tongji nianjian (Xinjiang Statistical Yearbook) 2010, China Statistics Press, Beijing.

${ }^{2}$ This term was coined by Rachel Harris (2002). The artists were Abdurehim Heyit, a native of Kashgar, and Ömärjan Alim, a native of Ghulja.

${ }^{3}$ Dao Lang (刀郎) is the phonetic transliteration in Chinese of 'Dolan'.

${ }^{4}$ The irony of this surprising English translation of the Chinese title will not be lost on anyone familiar with the ethno-politics of the region. See Bellér-Hann et al. (2007, pp. 4-6) for a discussion of the problems surrounding toponyms in Xinjiang. See Wang (2007) for a compelling account of contrastive perspectives on the Western Regions / East Turkestan and what these mean for Uyghur-Han relations.

${ }^{5}$ They include: 'Awariguli (a Uyghur love song)'; 'Tulufan de putao shu le (The Grapes of Turpan are Ripe)';

'Huar yu shaonian (Flowers and Youth)': a Hui song; and 'Zai na yaoyuan de difang (In That Faraway Place)': from Qinghai province in the North-west.

${ }^{6}$ Terra nullius is a Latin term meaning 'land belonging to no one'. In international law, a territory which has never been subject to the sovereignty of any state, or over which any prior sovereign has expressly or implicitly relinquished sovereignty, is terra nullius. Sovereignty over territory which is terra nullius can be acquired through occupation.

${ }^{7}$ The choice of name is significant: ' $I z$ (Traces)' is the title of three important Uyghur artistic creations dating from the mid-nineties: the poem and the novel titled 'Iz (Traces)' authored by the late nationalist writer Abdurehim Ötkür, and the cassette album 'Qaldi Iz (Traces)' released by singer-dutarist Ömärjan Alim (1995). For an English translation of the poem 'Iz (Traces)' see Allworth and Pahta (1988).

${ }^{8}$ This quotation, excerpted from the play Hamlet (1602) by William Shakespeare, has become a commonly used phrase indicating an unintentional apophasis. Where a speaker 'protests too much' in favour of some assertion, the idea may surface in others' minds that the assertion is false, something that they may not have previously considered.

${ }^{9}$ She is not alone in doing so. Chinese music critics have frequently credited Dao Lang with starting the trend of popularisation of Xinjiang music. See, for example, the American Chinese journalist who told Dao Lang at a press conference in 2013: 'You have set the example of successfully bringing regional music to the mass market' (Baidu 2013).

${ }^{10}$ The lyrics to 'On Erdaoqiao' contain the following: 'Ten years ago, you left your enchanting smile behind at Erdaoqiao; ten years after, I paced up and down this deserted street; now this bustling street has become more beautiful; yet in this busy bazaar area, I couldn't find you'. The irony lies in the fact that while Dao Lang along with other Han residents - considers the renovation of the Uyghur district in south-east Ürümchi an improvement, many locals and outside observers view the rebuild as a 'sanitisation' that has deprived the area of its original atmosphere, while bringing Hans into commercial roles where once were only Uyghur market stallholders. In this sense, another reading of this song is suggested: ten years before, the district was alive with the enchantment of indigenous culture, but ten years on, this can no longer be found.

${ }^{11}$ The ten tracks are all old revolutionary songs selected by Dao Lang. They include: 'Wo de zuguo (My Motherland)', which includes the line - 'if the wolf comes, we welcome it with a shotgun'; and 'Xiu hongqi (Sewing the Red Flag)', a song composed for the 1964 musical 'Jiang jie (Sister Jiang)', which is set towards the end of China's 'War of Liberation' (1946-9).
} 